\title{
Organizational Justice and Citizenship Behavior, the Mediating Role of Trust
}

\author{
Hassan ISMAIL (Lecturer) \\ Department of Human Resource Management, \\ Higher Institute of Business Administration (HIBA) \\ P.O.Box:12890 Damascus, Syria \\ E-mail: hassanisml@gmail.com
}

Doi:10.5296/ijhrs.v5i1.6757

URL: http://dx.doi.org/10.5296/ijhrs.v5i1.6757

\begin{abstract}
This study examines the role of organizational trust in the relationship between organizational justice and organizational citizenship behaviors (OCB). A total sample of 191 employees was selected from Syrian private banks. The research findings indicate that there is a significant positive impact of organizational justice dimensions (distributive, procedural, and interactional) on OCB. Similarly, organizational trust positively affects OCB. Furthermore, this study shows that organizational trust plays a mediating role in the relationship between the organizational justice and OCB.
\end{abstract}

Keywords: Organizational Justice, Distributive Justice, Procedural Justice, Interactional justice, Organizational Citizenship Behaviors, Organizational Trust.

\section{Introduction}

The study of organizational citizenship behavior (OCB) has been an important and central part of the literature. Research on OCB has been extensive since the introduction of its concepts in the 1980s (Bateman and Organ, 1983). The concept of OCB was initially proposed and studied in the US (Podsakoff et al., 1990). OCB refers to behavior that is not formally requested or directly rewarded but can be functional to the operations of an organization (Smith et al., 1983). The interest of researchers focused on determining the antecedents to OCB (Konovsky and Pugh, 1994). The notion of organizational justice has received considerable attention in industrial psychology, human resource management and organizational behavior researches. Organizational Justice, as an antecedent to OCB was supported by many studies (Mayer and Gavin 2005; Frazier et al., 2010). Along with organizational justice, organizational trust has frequently found as an antecedent of OCB (Moorman, 1991; Chegini, 2009; Guh et al., 2013). The relationship between organizational justice, trust and OCB has been identified as a plausible explanation for regulating the impact of organizational Justice on OCB (Konovsky and Pugh, 1994; Aryee et al,. 2002; Ertürk, 2007; Guh et al., 2013; Chhetri, 2014).

A review of OCB studies in Syria reveals, according to best knowledge of the researcher, that no 
study has included organizational justice, trust and OCB in one model. Thus, the purpose of this study is to explore the impact of three types of organizational justice (distributive, procedural, and interactional) and organizational trust on OCB in a developing country context, such as Syria. Furthermore, this study aims to investigate the mediating role of organizational trust on the relations between organizational justice and OCB in the Private Banks Sector. The rest of this paper is organized as follows: Section two provides the literature review. Research hypothesis are presented in section three. Section four introduces research methodology. Section five presents discusses the empirical results. The conclusion is given in section six.

\section{Literature review}

OCB represents "individual behavior that is discretionary, not directly or explicitly recognized by the formal reward system, and in the aggregate promotes the efficient and effective functioning of the organization". It includes five dimensions: conscientiousness, sportsmanship, civic virtue, courtesy, and altruism (Organ, 1988). These five dimensions cover such organizational behaviors as helping co-workers, following company rules, not complaining, and actively participating in organizational affairs. Conscientiousness refers to an employee performing his or her assigned tasks in a manner above what is expected. Sportsmanship as an employee's willingness to assume and carry out an extra temporary task, without complaining, may serve as an example of such behavior. Civic Virtue represents an individuals' behavior and indicates that they responsibly participate and rationally show concern about the life of the organization. Courtesy is a proactive gesture that considers consulting with other workers in the organization before acting, giving advance notice, and passing along information. Finally, Altruism is a category consisting of discretionary behaviors that aims at helping certain people in an organization with a relevant task or problem.

Most of the studies in the field of OCB have focused on the antecedents. These attempts have led to various antecedents including personality traits, characteristics of the tasks, leadership behaviors, and employee attitudes towards the job and organization (Podsakoff et al., 2000). The concept of justice is one of the important variables in OCB (Greenberg, 1999). Organizational justice refers to an individual's perception or evaluation of the appropriateness of some process or outcome (Cropanzano and Greenberg, 1997). Organizational justice is concerned with the rules developed to distribute or to take decisions on distribution of acquisitions such as tasks, goods, services, rewards, punishments, wages, organizational positions, opportunities and roles among employees and societal norms that constitute the basis for these rules (Folger and Cropanzano, 1998). However, researchers have generally agreed on three sources of organizational justice: distributive, procedural, and interactional (Cohen-Charash and Spector, 2001). Researchers have consistently found the three dimensions of organizational justice to be related, albeit differentially, to employee work-related attitudes and behaviors (Colquitt et al., 2001). Distributive justice describes the perceived fairness of the outcomes employees receive; it is a reflection of how valuable rewards, benefits and compensation from coordinated organizational efforts are fairly distributed among employees (Chou, 2009). Procedural justice describes the fairness of the procedures and process used to determine those outcomes and rewards (Robbins, 2005). Interactional justice is a unique perception of fairness in the interpersonal treatment of employees by an organization; it is the quality of treatment that the employee receives inside the workplace (Bies and Moag, 1986; Cropanzano and Greenberg, 1997).

Many empirical studies examined the relationship between organizational justice and OCB. The findings indicate that there is significant relationship between justice perceptions and OCB (Fassina et al., 
2008; Chegini, 2009; Chahal and Mehta, 2011; Zeinabadi and Salehi, 2011; Guh et al., 2013; Garg et al., 2013). Other researchers found that only two dimensions of organizational justice, i.e., procedural, and interactional justice were significantly and positively correlated with $\mathrm{OCB}$, but distributive justice was not able to predict OCB (Moorman, 1991; Niehoff and Moorman, 1993; Mohammad et al., 2010). Viswesvaran and Ones (2002) study found that procedural justice and distributive justice are related to OCB.

Trust is the willingness of a party to be vulnerable to the actions of another party, based on the expectation that the other will perform a particular action important to the trustor, irrespective of the ability to monitor or control that other party (Mayer et al., 1995). Gilbert and Tang (1998) described organizational trust as "a feeling of confidence and support in an employer, it refers to employee faith in corporate goal attainment and organizational leaders, and to the belief that ultimately, organizational action will prove beneficial for employees." They further believed that the determinants of organizational trust are: work group cohesion, friendship centrality, and receiving information through social integration and mentoring. Trust is an important factor in maintaining the exchange relationship between superiors and subordinates. Employees who feel that the organization is fair and more trustful are willing to engage in behavior that is beneficial to the organization (McCauley and Kuhnert, 1992).

Trust does not exist only as a form between individuals, but also between members and organizations (Costigan et al., 1998). Scott (1981) developed four trust measures based on interpersonal relationships. The four categories include: trust in immediate supervisor, trust in peer group/work unit, trust in top management, and trust in the management development consultant. Tan and Tan (2000) distinguished between two main referents of trust that are namely trust in organization and trust in supervisor; and they argue that these referents are distinct but related constructs. Their study showed that although trust in supervisor was more strongly associated with variables such as ability, benevolence, and the integrity of the supervisor, trust in organization was more strongly correlated with variables such as perceived organizational support and justice.

Guh et al (2013) study showed that organizational justice influences institutional trust. Masterson et al (2000) study showed a positive meaningful relationship between organizational justice and organizational Trust. Their study indicated a strong relationship between procedural justice and organizational trust, but there was no significant relationship between distributive justice and interpersonal trust. According to Beugre (1998), all justice dimensions have positive relations with trust because when people feel that they are fairly treated, they will tend to have confidence in the organization and their managers. The study of Frazier et al (2010) has provided support that organizational justice has a significant relationship with trust. They found also that procedural justice and interpersonal justice (a part of interactional justice) lead to the formation of trust in organization while informational justice (another part of interactional justice) leads to the formation of trust in supervisor. Aryee et al (2002) in their study found that distributive, procedural and interactional justice lead to formation of trust in organization while only interactional justice led to formation of trust in supervisor. Aboul-Ela (2014) predicted linkages between distributive, procedural, interpersonal and informational justice and employee trust. This study revealed that interpersonal justice has a more positive impact on employees' trust than informational justice. Based on the findings of (Konovsky et al., 1994), trust has a stronger relationship with both interpersonal justice and informational justice.

Trust is an important factor in the relationship between superiors and subordinates (McCauley and Kuhnert, 1992). Most of previous studies have demonstrated that trust enhances people's willingness to 
engage in spontaneous sociability such as cooperative and altruistic behavior (Poon, 2006). Some studies indicated a direct effect of organizational trust on OCB (Podsakoff, et al., 1990; McAllister, 1995). Few researches, such as Guh et al (2013), showed that there was no direct effect of trust on OCB.

Understanding organizational justice and trust is extremely important for organizations because of its relationship with OCB. Organizational justice involves the perceptions of organizational members regarding the fairness of their conditions of employment. Organizational Justice, as an antecedent to OCB was supported in similar studies (Mayer and Gavin 2005; Frazier et al., 2010). Trust has been identified as a plausible explanation for regulating the impact of organizational Justice on OCB (Konovsky and Pugh 1994; Aryee et al., 2002). Researchers have used social exchange theory as an explanation for the role of trust in mediating the relationship between justice perception and OCB (Aryee et al., 2002; Frazier et al., 2010). Guh et al (2013) study showed the mediating effects of institutional trust on the relationship between organizational justice comprising distributive justice, procedural justice, and interactional justice and OCB.

\section{Research hypothesis}

According to the preceding review, the present study aims to test the following hypothesis:

H1. Organizational justice has a significant impact on OCB.

H2. Organizational justice has a significant impact on organizational trust.

H3. Organizational trust has a significant impact on OCB.

H4. Organizational trust mediates the relationship between organizational justice and OCB.

\section{Research methodology}

\subsection{Data collection and sample}

Data have been collected from both primary and secondary sources. Secondary data were collected through comprehensive literature review. The primary data were collected from private banks in Syria. A total sample of 191 employees was selected from banking sector. Questionnaire related to the study variables was the main tool of this study.

\subsection{Measures}

The questionnaire included five sections, including organizational justice, trust, organizational citizenship behaviors, and basic demographic information. Apart from basic demographic information, a 5-point Likert scale format was used, and the scores on the scale ranges from $1=$ Strongly Disagree to $5=$ Strongly Agree.

i.

\subsubsection{Organizational Justice Scale (OJS)}

To measure organizational justice, scale developed by Niehoff and Moorman (1993) has been used in the study. The scale consists of three factors: distributive justice (5 items, reported reliability for 0.88), 
procedural justice (6 items, reported reliability for 0.84 ) and interactional justice (9 items, reported reliability for 0.90$)$.

ii.

\subsubsection{Organizational Trust Scale (OT):}

To measure organizational trust, trust in organization scale developed by Robinson (1996) has been used in the study. The scale consists of 7 items. The scale has reported reliability for 0.94 .

iii.

\subsubsection{OCB Scale}

OCBs were measured with Podsakoff et al (1990) Organizational Citizenship Behavior Questionnaire (OCBQ) consisting of the five factors identified by Organ (1988): conscientiousness (5 items, reported reliability for 0.91 ), sportsmanship ( 5 items, reported reliability for 0.87 ), courtesy (5 items, reported reliability for 0.88 ), civic virtue (4 items, reported reliability for 0.80 ), and altruism (5 items, reported reliability for 0.84$)$. The overall OCB scale has reported reliability for 0.95 .

\section{Results and discussion}

This study attempts to understand the relationships among organizational justice dimensions (distributive, procedural, and interactional), trust, and OCB.

Table 1 displays the means and standard deviations of all variables. Table 2 presents the results of a multiple regression analysis regarding the effects of organizational justice dimensions (distributive, procedural, and interactional) and trust on OCB.

Table 1. Means and standard deviations

\begin{tabular}{|l|l|l|l|l|}
\hline & $\mathrm{N}$ & Mean & Std. Deviation & Std. Error Mean \\
\hline DJ & 191 & 3.64 & 1.143 & .083 \\
\hline PJ & 191 & 2.96 & 1.408 & .102 \\
\hline IJ & 191 & 3.10 & 1.503 & .109 \\
\hline OT & 191 & 3.71 & 1.034 & .075 \\
\hline OCB & 191 & 3.36 & 1.458 & .105 \\
\hline
\end{tabular}

Table 2. Regression analysis results: organizational justice's sub-dimensions and trust on OCB

$$
\text { Variable }
$$

Model 1

Model 2 


\begin{tabular}{|c|l|l|}
\hline Organizational justice & & \\
\hline \multicolumn{1}{|c|}{ Distributive justice } & $.562(.000)$ & \\
\hline Procedural justice & $.184(.004)$ & \\
\hline Interactional justice & $.353(.000)$ & \\
\hline Organizational trust & & $1.287(.000)$ \\
\hline $\mathrm{R}^{2}$ & .769 & .833 \\
\hline $\mathrm{F}$ & $207.277(.000)$ & $940.228(.000)$ \\
\hline
\end{tabular}

Model 1 in table 2 captures the direct effects of organizational justice dimensions (distributive, procedural, and interactional) on the dependent variable (OCB). This model is significant at $5 \%$ level $\left(\mathrm{R}^{2}\right.$ $=.769$ ). Coefficients of distributive, procedural, and interactional justice are positive and significant for OCB ( $p<0.05)$. These findings indicate that banks would achieve a higher level of OCB if they develop a well policy in organizational justice (distributive, procedural, and interactional). Accordingly, the results support Hypothesis 1, which states that organizational justice (distributive, procedural, and interactional) significantly impact OCB.

Next, the direct effect of organizational trust on the dependent variable (OCB) is examined. Model 2 in table 2 is significant at the $5 \%$ level $\left(\mathrm{R}^{2}=.833\right)$. Coefficients of organizational trust is positive and significant for OCB $(\mathrm{p}<0.05)$. These findings indicate that banks would achieve a higher level of OCB if they create a better climate of trust. Accordingly, the results support Hypothesis 3 which states that organizational trust significantly impact OCB.

Table 3 shows the results of a multiple regression analyses of the effect of organizational justice dimensions (distributive, procedural, and interactional) on organizational trust.

Table 3. Regression analysis results: organizational justice's sub-dimensions on organizational trust

\begin{tabular}{|l|l|}
\hline Variable & Model 3 \\
\hline Organizational justice & \\
\hline Distributive justice & $.439(.000)$ \\
\hline Procedural justice & $.107(.004)$ \\
\hline Interactional justice & $.299(.000)$ \\
\hline $\mathrm{R}^{2}$ & .911 \\
\hline
\end{tabular}


$\mathrm{F}$

$637.077(.000)$

Model 3 in table 3 shows the impact of organizational justice (distributive, procedural, and interactional) on organizational trust. This model is significant at the $5 \%$ level $\left(\mathrm{R}^{2}=.911\right)$. Coefficients of distributive, procedural, and interactional justice are positive and significant for organizational trust $(\mathrm{p}<0.05)$. These findings indicate that banks would achieve a higher level of trust if they develop a well policy in organizational justice (distributive, procedural, and interactional). Accordingly, the results support Hypothesis 2, which states that organizational justice (distributive, procedural, and interactional) significantly impact organizational trust.

This study follows Baron and Kenny's (1986) procedure to analyze the mediating role of organizational trust between organizational justice dimensions (distributive, procedural, and interactional) and OCB. The first step is to examine the relationship between independent variable and the dependent variable. As model 1 in Table 2 shows, all organizational justice factors (distributive, procedural, and interactional) are significantly related to OCB. The second step is to examine the relationship between independent variable and the mediator variable. As model 3 in Table 3 shows, all organizational justice factors (distributive, procedural, and interactional) are significantly related to organizational trust. The third step is to examine the effect of the mediator, organizational trust, on the dependent variable, OCB. The results of model 2 in Table 2 indicate that, the organizational trust factor has positive and significant effects on OCB. The fourth step is to include the mediator, organizational trust, in the models to examine whether it reduces the effects of the antecedents to non-significance. As model 4 in Table 4 shows, organizational trust significantly reduces the effects of organizational justice factors (distributive, procedural, and interactional) on the dependent variable, all of them to non-significance. Thus, organizational trust plays a mediating role between organizational justice (distributive, procedural, and interactional) supporting the mediation effect in Hypothesis 4.

Table 4. Regression analysis results: the mediating role of organizational trust on the relationship between organizational justice's sub-dimensions and OCB

\begin{tabular}{|c|l|}
\hline Variable & Model 4 \\
\hline Organizational justice & \\
\hline Distributive justice & $.034(.677)$ \\
\hline Procedural justice & $.055(.320)$ \\
\hline Interactional justice & $-.006-(.927)$ \\
\hline Organizational trust & $1.203(.000)$ \\
\hline $\mathrm{R}^{2}$ & .834 \\
\hline $\mathrm{F}$ & $233.006(.000)$ \\
\hline
\end{tabular}


Conclusion

This research, on the whole, provides valid empirical findings and demonstrates whether the organizations surveyed have created a good level of OCB due to organizational justice and trust policies and practices conducted.

From the findings, it appears that the private banks are becoming more aware of the need to understand their employees' perceptions/reactions to the organizational justice and trust. While there are obvious advantages in understanding employees' perceptions and reactions to organizational justice and trust, linking of those reactions to OCB is more important. This study provides empirical evidence of the impact of all organizational justice dimensions (distributive, procedural, and interactional) on OCB. The study demonstrates that employees' perceptions of distributive, procedural, and interactional justice positively predict employees' OCB in Syrian contexts. This result is in consistent with previous research that found all organizational justice dimensions are able to predict OCB (Fassina et al., 2008; Chegini, 2009; Chahal and Mehta, 2011; Zeinabadi and Salehi, 2011; Jafari and Bidarian, 2012; Guh et al., 2013). However, this study is slightly different from other studies that indicated distributive and interactional justice to be significantly correlated with OCB but not procedural justice (Moorman, 1991; Niehoff and Moorman, 1993; Mohammad et al., 2010), and procedural justice and distributive justice are related to OCB but not interactional justice (Viswesvaran and Ones, 2002; Garg and Kataria, 2013).

Results show that organizational justice influences organizational trust. This result is in consistent with previous researches that found all organizational justice dimensions are able to predict the organizational trust (Beugre, 1998; Masterson et al., 2000; Frazier et al,. 2010; Jafari and Bidarian, 2012; Aboul-Ela, 2014).

This study proves the mediating effect of organizational trust in the relationship between organizational justice (distributive, procedural, and interactional) and OCB of the employees of private banks in Syrian. This result is in consistent with previous researches (Pugh 1994; Aryee et al., 2002; Frazier et al., 2010; Guh et al., 2013). The findings suggest that organizational justice would promote employees' organizational trust and employees would show more emotional attachment to the bank and would show more OCB to reciprocate the fairness offered by the bank.

\section{Bibliography}

[1] Aboul-Ela, G.M. (2014). Analyzing the relationships between organization justice dimensions and selected organizational outcomes - empirical research study. The Business \& Management Review, 5 (2), 34-44.

[2] Aryee, S., Budhwar, P. S., and Chen, Z. X (2002). Trust as a mediator of the relationship between organizational justice and work outcomes: test of a social exchange model. Journal of Organizational Behavior, 23 (3), 267-285.

[3] Baron, R.M., and Kenny D.A. (1986). The moderator-mediator variable distinction in social psychological research: conceptual, strategic, and statistical considerations. Journal of Personality and Social Psychology, 51 (6), 1173-82.

[4] Bateman, T.S., and Organ, D.W. (1983). Job satisfaction and the good soldier: the 
relationship between affect and employee citizenship. Academy of Management Journal, 299-322.

[5] Beugre, C. (1998). Managing fairness in organizations. Westport, CT: Quorum Books Co.

[6] Jafari, P., and Bidarian, S. (2012). The relationship between organizational justice and organizational trust. Procedia - Social and Behavioral Sciences, 47, 1622 - 1626.

[7] Bies, R.J., and Moag, J.S. (1986). Inleractional justice: communication criteria of fairness. Research on Negotiation in Organizations, 1, 43-55.

[8] Chahal, H., and Mehta, S. (2011). Antecedents and consequences of organisational citizenship behaviour (OCB): a conceptual framework in reference to health care sector. Journal of Services Research, 10, 25-44.

[9] Charash, V.C., and Spector, P.E. (2001). The role of justice in organizations. a metaanalysis. Organizational Behavior and Human Decision Processes, 86 (2), 278-321.

[10]Chegini, M. (2009). The relationship between organizational justice and organizational citizenship behavior. American Journal of Economics and Business Administration, 1 (2), 171-174.

[11]Chhetri, P. (2014). The role of cognitive and affective trust in the relationship between organizational justice and organizational citizenship behavior: a conceptual framework. Business: Theory and Practice, 15 (2), 170-178.

[12] Chou, R. (2009). Organizational justice and turnover intention: a study of direct care workers in assisted living facilities for older adults in the United States. Social Development Issues, 31, 69-85.

[13] Cohen-Charash, Y., and Spector, P.E. (2001). The role of justice in organizations: a metaanalysis. Organizational Behavior and Human Decision Process, 86, 278-321.

[14] Colquitt, J.A., Conlon, D.E., Wesson, M.J., and Porter, C. N. (2001). Justice at the millennium: a meta-analytic review of 25 years of organizational justice research. Journal of Applied Psychology, 86, 425-445.

[15] Costigan, R.D., Ilter, S.S., and Berman, J. J. (1998). A multi-dimensional study of trust in organizations. Journal of Managerial Issues, 10, 303-317.

[16]Cropanzano, R., and Greenberg, J. (1997). Progress in organizational justice: tunneling ihrough the maze. International Review of Industrial and Organizational Psychology, 317-372.

[17]Ertürk, A. (2007). Increasing organizational citizenship behaviors of Turkish academicians: mediating role of trust in supervisor on the relationship between organizational justice and citizenship behaviors. Journal of Managerial Psychology, 22 (3), 257-270.

[18]Fassina, N.E., Jones, D. A., and Uggerslev, K.L. (2008). Meta-analytic tests of relationships between organizational justice and citizenship behavior: testing agent-system and shared-variance models. Journal of Organizational Behavior, 29, 805-828.

[19]Folger, R., and Cropanzano, R. (1998). Organizational Justice and Human Resource Management. Beverly Hills: CA, Sage Publications.

[20]Frazier, M.L., Johnson, P.D., Gavin, M., Gooty, J., and Snow, D.B. (2010). 
Organizational justice, trustworthiness, and trust: a multifociexamination. Group \& Organization Management, 35 (1), 39-76.

[21] Garg, P., Rastogi, R., and Kataria, A. (2013). The influence of organizational justice on organizational citizenship behaviour. International Journal of Business Insights \& Transformation, 6 (2).

[22] Gilbert, J. and Tang, T. (1998). An examination of organizational trust antecedents. Public Personnel Management, 27 (3), 321-338.

[23] Greenberg, J. (1999). Organization justice: yesterday, today and tomorrow. Journal of Management, 16 (2), 399-432.

[24] Guh, W.Y., Lin, S.P., Fan, C J., Yang, C.F. (2013). Effects of organizational justice on organizational citizenship behaviors: mediating effects of institutional trust and affective commitment. Psychological Reports: Human Resources \& Marketing, 112 (3), 818-834.

[25] Konovsky, M.A., and Pugh, S.D. (1994). Citizenship behavior and social exchange. Academy of Management Journal, 37, 656-669.

[26] Masterson, S.S., Lewis, K., Goldman B.M., and Taylor, M.S. (2000). Integrating justice and social exchange: the differing effects of fair procedures and treatment of work relationships. Academy of Management Journal, 43, 738-748.

[27] Mayer, R.C., Davis, J.H., and Schoorman, F.D. (1995). An integrative model of organizational trust. Academy of Management Review, 20 (3), 709-734.

[28] Mayer, R.C., and Gavin, M.B. (2005). Trust in management and performance: the boss? Academy of Management Journal, 48 (5), 874-888.

[29] Mcallister, D.J. (1995). Affect-and-cognition-based trust foundations for interpersonal cooperation in organizations. Academy of Management Journal, 38 (1), 24-39.

[30] Mccauley, D.P., and Kuhnert, K.W. (1992). A theoretical review and empirical investigation of employee trust. Public Administration Quarterly, 16 (2), 265-284.

[31] Mohammad, J., Binte-Habib, F.Q., and Adnan, M. (2010). Organizational justice and organizational citizenship behavior in higher education institution. Global Business and Management Research: An International Journal, 2, 13-32.

[32] Moorman, R.H. (1991). The relationship between organizational justice and organizational citizenship behaviors: do fairness perceptions influence employee citizenship? Journal of Applied Psychology, 76 (6), 845- 855.

[33] Niehoff, B.P., and Moorman, W.V. (1993). Justice as a mediator of the relationship between methods of monitoring and organizational citizenship behavior. Academy of Management Journal, 36 (3), 209-776.

[34] Organ, D.W. (1988). Organizational citizenship behavior: The good soldier syndrome. Lexington: Lexington, MA.

[35]Podsakoff, P.M., MacKenzie, S.B., Moorman, R.H., and Fetter, K. (1990). Transformational leader behaviors and their effects on followers' trust in leader, satisfaction, and organizational citizenship behaviors. Leadership Quarterly, 1, 107-142.

[36] Podsakoff, P.M., MacKenzie, S.B., Paine, J.B., and Bachrach, D.G. (2000). Organizational citizenship behaviors: a critical review of the theoretical and empirical literature and suggestions for future research. Journal of Management, 26, 513-563.

[37]Poon, J.M. (2006). Trust in supervisor and helping coworkers: moderating effect of 
perceived politics. Journal of Managerial Psychology, 21 (6), 518-532.

[38] Robbins, S.P. (2005). Organizational behavior. (Eleventh ed.). Prentice Hall of India.

[39] Robinson, S.L. (1996). Trust and breach of the psychological contract. Administrative Science Quarterly, 41, $574-599$

[40] Scott, D. (1981). The development of four new organizational measures of trust. In Butler, J.K. (1991). Toward understanding and measuring conditions of trust: evolution of a condition. Journal of Management, 17, (3), 643-663.

[41] Smith, C.A., Organ, D.W., and Near, J.P. (1983). Organizational citizenship behavior: its nature and antecedents. The Journal of Applied Psychology, 68, 653-663.

[42] Tan, H. and Tan, C.S.F. (2000). Towards the differentiation of trust in supervisor and trust in organization. Genetic, Social and General Psychology Monographs, 2, 241-260.

[43] Viswesvaran, S., and Ones, D.S. (2002). Examining the construct of organizational justice: a meta-analytic evaluation of relations with work attitudes and behaviors. Journal of Business Ethics, 38, 193-203.

[44]Zeinabadi, H., and Salehi, K. (2011). Role of procedural justice, trust, job satisfaction, and organizational commitment in organizational citizenship behavior (OCB) of teachers: proposing a modified social exchange model. Procedia - Social and Behavioral Sciences, $29,1472-1481$. 